\title{
Herke Boglárka
}

\section{SZAKMAI ÉLETÚTINTERJú LANNERT JUDIT OKTATÁSSZOCIOLÓGUSSAL' \\ DOI 10.35402/kek.2020.1.7}

\begin{abstract}
Absztrakt
A Budapesti Corvinus Egyetem Szociológia Doktori Iskolájában 2018 tavaszán interjús kutatást végeztünk olyan doktori fokozattal rendelkező kutató szociológusok körében, akik a Doktori Iskolában szerezték a doktori fokozatukat vagy karrierjük valamely szakasza köthető az Egyetemhez. A kutatás elsődleges célja a kutatók szakmai életútjának feltárása volt, emellett az interjúk során rákérdeztünk a doktori képzéssel kapcsolatos véleményekre és a fiatal kutatóknak szánt tanácsokra is. Lannert Judit életútja a hagyományos értelemben vett akadémiai szférán kívüli tudományos pályára kiváló példa, mely karrierútról általában kevesebbet lehet olvasni. Az interjú közlésével ennek a karrierpályának az ismertetéséhez kívánunk hozzájárulni. ${ }^{2}$
\end{abstract}

\begin{abstract}
At the Doctoral School of Sociology of Corvinus University of Budapest (CUB) we conducted career path interviews with Ph.D. holder researcher sociologists in the spring of 2018. We interviewed researchers who obtained their $\mathrm{Ph} . \mathrm{D}$. at the school, or whose career at some point was connected to the university. The main role of the research was to explore the career paths of researchers, however, during the interviews, we also asked their opinions regarding the doctoral training, and their pieces of advice to young researchers. The career path of Judit Lannert is an excellent example of a researcher career outside the academy. By publishing this interview we would like to contribute to the familiarization of this kind of career path.
\end{abstract}

1 A szakmai életútinterjú 2018. április 17-én készült a Budapesti Corvinus Egyetemen.

2 Kutatócsoportunk ezúton mond köszönetet Lannert Juditnak, hogy hozzájárult az interjú közléséhez. A kutatás az Európai Unió, Magyarország és az Európai Szociális Alap társfinanszírozása által biztosított forrásból az EFOP-3.6.3-VEKOP-16-2017-00007 azonosítószámú „Tehetségből fiatal kutató - A kutatói életpályát támogató tevékenységek a felsőoktatásban” című projekt keretében jött létre.

\section{„Úgy érzem magam, mint Miss Marple, hogy van egy adatbázis, egy probléma, és akkor keressük a tettest, és a végén kideritjük" \\ K: Ha a kutatói életpályájára gondol, akkor Ön szerint mikor és hogyan kezdödött?}

V: Ez így nehéz kérdés, hogy mikor kezdődött, talán az egyetem után. Külkereskedelmi szakon végeztem, és az egyetem után az Interkoncertbe mentem el dolgozni, de nagyon hamar rájöttem, hogy énnekem nem ez a terepem. Akkor direkt elmentem egy nevelőotthonba dolgozni, csak azért, hogy több időm legyen olvasgatni, írogatni, és akkor bementem az akkori Oktatáskutató Intézetbe, ami ott volt a Victor Hugo utcában, hogy nincs-e valami munka. Adtak is interjúzni valót, meg szakirodalmakat, hogy foglaljam össze, és az egyik ilyen elemzés annyira jól sikerült, hogy amikor 1990-ben megalakult az Országos Közoktatási Intézet, akkor engem odahívtak. Vagyis igazából egy ilyen partizánakcióval kerültem oda (igaz, hogy a szakdolgozatom is oktatásról szólt). Tehát a külker tanszéken végeztem ugyan, de valahogy nem igazán fogott meg a kereskedelem, és ezért mentem az Interkoncertbe. Zenéltem, meg szerettem a zenét, de végül is nem ezen a pályán helyezkedtem el. Körülbelül ennyi. Talán még érdemes megemlíteni, hogy a munkahelyeim, a nevelőotthon is egy nagyon jó tapasztalat volt a későbbi kutatói pályám szempontjából. Nagyon hamar szembesültem budai úrilányként a roma helyzettel, meg az egyéb szegénysorsú gyerekek helyzetével, és utána én még elmentem a Közvéleménykutatóba kérdezőnek. Az is egy érdekes történet, hogy ott annak idején csináltak egy pszichológiai elemzést, egy vizsgálatot az összes munkatárssal. Ez még ugye '87, tehát még a Kádár-korszak. És én ott kérdőíveztem, ami szintén nagyon érdekes volt, mert fiatalként megkaptam a nehezebb terepeket. Tehát vidéken és Budapesten is a VII., VIII., IX. kerületet, ahol nem mindig voltak barátságosak, de nagyon sokat tanultam ezekből a kérdezésekből. Az IQ meg a pszichológiai vizsgálat alapján viszont valahogy nekem az jött ki, hogy (nevet)... Akik még férfiak nem csinálták meg addig az IQ tesztet, ők utána már nem voltak hajlandók megcsinálni, mert féltek, hogy alulmaradnak. $\mathrm{Na}$ 
mindegy. Ez csak azért volt vicces, mert én addig is ott dolgoztam, de egy ilyen teszt kellett ahhoz, hogy azt mondják, hogy tényleg, lehet, hogy engem valami másra is lehet használni, és akkor én kezdtem el csinálni a kérdőíveket a TÁRKI-val elég szoros együttműködésben. Ha úgy vesszük, akkor az én kutatói munkám nagyon alulról indult, amit én utólag nagyon szerencsésnek gondolok. Tehát nagyon az alapoktól, kérdezőbiztosként, kérdőívszerkesztőként és emellett interjúkat csináltam az Oktatáskutató Intézetnek, illetve másodelemzéseket. Tudom, hogy az, ami nagyon megtetszett nekik, az a japán oktatási reformról szóló anyagom volt. Adtak nekem két-három angol nyelvű tanulmányt, azt én összefoglaltam, és az annyira jól sikerült, hogy meg is jelent (Lannert 1988). Tehát igazából így történt az, hogy én '90-ben az Országos Közoktatási Intézetbe kerültem, ami újonnan indult a megszűnt OPI helyett, Zsolnai József vezetésével. Az Oktatáskutató Intézet egy részét is odavitték, és én az ottani kutatási központban '90-ben avanzsáltam tulajdonképpen kutatóvá.

K: Szociálpolitika szakot is végzett. Annak esetleg volt valamilyen hatása arra, hogy ilyen irányban kezdett el kutatni?

V: Igen, a szociálpolitika az úgy jött, hogy a nevelőotthonban szembesültem ezzel a problémával, és kicsit többet akartam megtudni róla. És a szociálpolitika szak nagyon új volt akkor, tehát ez is vonzó volt. Azt hiszem '86-ban indult a szak Ferge Zsuzsa irányításával, és én a következő évben, '87ben kezdtem. Akkor egyébként még a szociológia is egy viszonylag új dolog volt Magyarországon, de azért az már volt. A szociálpolitika viszont akkor indult. Nagyon izgalmas volt, de most utólag azt mondanám, hogy amit ott tanultam, azt kevéssé hasznosítottam, viszont nagyon izgalmas emberekkel találkoztam. 20 gyerekes cigány költőtől kezdve a volt pártbizottsági káderig, papig, rendőrig, tehát ott olyan emberekkel találkoztam, akikkel egyébként nem találkoztam volna. Ebben az értelemben biztos, hogy bizonyos kompetenciákat fejlesztett a képzés, egy szemléletet adott, megismerkedtem a problémákkal, emberekkel.

K: És az oktatás, mint kutatási téma az minek vagy kinek a hatására kezdte el érdekelni?

V: Ez az, amire már nem emlékszem, mert már a szakdolgozatomat is oktatásból írtam, az alap- képzésen, ami ugye akkor még nem volt osztott képzés, tehát az öt év után írtam. Talán, ha még korábbra megyünk, a mi időnkben volt kisdobos, úttörő, ifivezető. Én ifivezető is voltam, de semmi mozgalmi dolgot nem csináltam, hanem rengeteget kirándultunk, és a másik tevékenység az volt, hogy a volt általános iskolámba visszamentem, ahol gyerekcsoportokkal foglalkoztam. Emlékszem, hogy akkor majd megőrültem a maja és az azték kultúráért, meg az írásukért, és akkor (nevet) szerencsétlen tizenéves általános iskolás gyerekekkel a maja számokat és a betűket tanultuk meg. Szóval nem is tudom, nagyon kisgyerekként is a babáimmal azt játszottam, hogy körbe leültettem őket, volt egy táblám és magyaráztam nekik, szóval nem ruhákkal játszottam, nem öltöztettem őket. Valószínü, hogy a tanári hivatás vonzott, de nagyon hamar rájöttem, hogy én tanárnak nem lennék jó. Nem vagyok elég türelmes, és magamat is elunom, ha ugyanazt kétszer kell elmondani, és ebből lett valószínűleg az, hogyha nem is tanár, akkor kutató. És ami még hozzájött, hogy írni mindig nagyon jól írtam. Tehát az már alsóban is - emlékszem -, hogy a fogalmazásaim jók voltak. Eleinte műfordító akartam lenni tizenévesen, de aztán ezek így valahogy összeadódtak. Ugye mi is már benne voltunk abban a problémában, most pedig még erőteljesebben így van, hogy nincsenek már homogén foglalkozások. Tehát nem mondhatnám, hogy én olyan nagyon céltudatosan mentem volna az utamon. Arra mentem, ami érdekelt, és ezek az érdeklődések, meg az én kompetenciáim bevittek ebbe az irányba. 1990ben, amikor én az Országos Közoktatási Intézetbe beléptem kutatóként, akkor indult az a pálya, amit azóta is csinálok.

K: A PhD-fokozatot 2005-ben szerezte, addig viszonylag elég sok idö eltelt, erröl az idöszakról tudna-e egy kicsit mesélni? Egyrészt arra lennék kiváncsi, hogy miért döntött úgy, hogy majd PhD képzésre iratkozik, illetve, hogy milyen út vezetett addig.

V: Amikor én '90-ben beléptem az Országos Közoktatási Intézetbe, akkor mögöttem volt ugye már a Közvéleménykutató Intézetben szerzett empirikus tapasztalat, hogy ki kellett menni a terepre, interjúkat csinálni, kérdőíveket szerkeszteni. Egyébként ez a kérdőívszerkesztés az egyik legjobban hasznosuló kompetenciám volt, amit az egyetemi képzés is segített, mert ugyan az informatikai képzés nem volt erős, de a blokkdiagramok révén kialakult az a fajta logikus gondolkodás, hogy ho- 
gyan kell egy kérdőívet felépíteni, és hogyan kell elugrasztani a kérdéseket satöbbi. És akkor beléptem, és elindult egy tanulási folyamat, a „learning by doing", az nagyon erőteljes volt. Sikerült egy SPSS szoftvert szerezni, hogy honnan és hogyan én nem tudom, de teljesen autodidakta módon kezdtem el használni az SPSS-t, és emlékszem, hogy az első megjelent tanulmányom, az talán '94-ben volt, mármint ami az OKI-ban jelent meg, az ifúsági munkanélküliségről szólt (Lannert 1993), és akkor az már valamilyen kérdőív, adatbázis, szoftver alapján készült. Tehát a kérdőívezésből, kérdőívszerkesztésből indultam, és én persze tanultam statisztikát a közgázon, de azért az más jellegű volt. Főleg gazdasági statisztika volt, termésátlagok meg a raktározás optimalizálása, rémesen unalmas dolgok. Utólag azt gondolom, hogyha más feladatok lettek volna, lehet, hogy hamarabb megtanulom jól azt a statisztikát, de mindenesetre elkezdtem ezzel foglalkozni. És azt kell tudni, hogy azért a rendszerváltással és a felsőoktatás átalakulásával én a '90-es években pont abban a helyzetben voltam, hogy akkor még nem volt PhD képzés, hanem helyette volt a kandidátusi rendszer. Amit lehetett volna csinálni, be kellett volna adni valamit és akkor azt elismerik, de közben én meg elkezdtem gyerekeket szülni. Tehát ugye az történt, hogy dolgoztam, aztán voltunk külföldön is, a férjem kapott ösztöndíjat Princetonba, egy évig ott voltunk, megszületett a második gyerek, visszajöttünk. Nagyon izgalmas és sűrű volt az élet, és mire azt gondoltam volna, hogy itt az ideje kandidálni, megváltozott a rendszer, a PhD esetében viszont már sokkal szigorúbb elvárások voltak, mint a kandidátusi rendszerben. Azt hiszem 3 évünk volt, hogy megcsináljuk a doktori dolgozatot, most már pontosan nem emlékszem, mert senki nem csinálta meg ennyi idő alatt. Én sem. Nahát így történt, és hogy mire idáig eljutottam és összeszedtem magam, hogy akkor ez legyen, akkor tulajdonképpen már a harmadik gyerek is megvolt. Hál' istennek a munkahely a PhD-t nagyon pártolta, ráadásul én lettem a Kutatási Központ vezetője, tehát minden értelemben volt egy nagy támogatás a munkahelyről. Otthonról is, meg kell mondanom az apósom rengeteget segített a három gyerekkel, tisztába rakta őket, satöbbi. Enélkül biztos, hogy nem ment volna, tehát ha nincsen ilyen otthoni segítség. És amikor én erre a PhD-ra jelentkeztem, akkor nem voltam egyedül, legalább négyen-öten voltunk ilyen korombeli nők. Tipikusan azok a nők, akik a '90es években házasodtak, gyereket szültek, és mégis kutatói pályára léptek, azok a PhD képzésbe túlko- rosan léptek bele. Nem éreztem annyira furcsának ezt a dolgot, mert voltak mások is hasonló cipőben. Az persze más dolog volt, aki évekkel fiatalabb volt, meg mondjuk volt olyan, hogy egy terembe bementünk, akkor jöttek a nem PhD-s, hanem sima egyetemisták, és állandóan csókolomoztak, ez állati idegesítő volt. De a másik oldalon meg azt gondolom, és szerintem ez ma már szinte kötelező, hogy nem jó tapasztalatszerzés nélkül végigmenni az iskolarendszeren. Ha úgy mentem volna végig, akkor tulajdonképpen nem látok semmit abból, amit így viszont láttam a munkáim során. Ha ez nem lett volna, akkor valószínűleg sokkal éretlenebbül és zöldebben kerülök ebbe az egészbe. Amikor bekerültem ebbe a PhD-ba, akkor már nagyon tudtam, hogy mit akarok. Így se volt könnyủ megtalálni a $\mathrm{PhD}$ témámat, de azért már nagyon tudtam, hogy mi az a terület, mit akarok, egy csomó dolgon már túl voltam, tehát ilyen értelemben azt gondolom, hogy szerencsés volt ez a késedelem.

K: Emlitette, hogy a Közoktatási Intézetben támogatóan álltak ahhoz, hogy Ön PhD képzésre járjon, ez hogyan nyilvánult meg, miben támogatták?

V: Ez nem anyagiakban meg időkedvezményben nyilvánult meg, ami szokott lenni, már csak azért sem, mert az egy aranyélet volt, heti két kutatónapunk volt. Most visszagondolva amellett simán meg tudtam csinálni. Olyan értelemben volt támogatás, hogy elvárták, hogy csináljam, és ami a doktori témám lett, azt egy ottani kutatás alapján csináltam, amit ugye a kollégákkal meg tudtam beszélni. Amikor a védés volt, akkor szinte mindenki eljött, ott tolongtak az Intézetből. A fönököm fel is szólalt és meg is dicsért, tehát volt ennek egy ilyen nagyon pozitív feelingje.

K: A munkatársi közösségröl tudna-e még egy kicsit beszélni, hogy milyen volt ott a kutatócsoport?

V: Ugye az Országos Közoktatási Intézet az a Pedagógiai Intézetből alakult át, és ez azt jelentette, hogy az egy nóvum volt, hogy amikor az oktatásról beszélünk, akkor nem csak a tantárgyakat nézegetjük, és tankönyveket csinálunk - az is volt, meg tantárgyelmélet meg satöbbi és fejlesztés -, hanem szociológiai értelemben kutatunk is. Ezen a téren az én főnököm, Halász Gábor volt az, aki behozta már az Oktatáskutató Intézetből (oda pedig annak idején az ő fönöke Kozma Tamás) ezt a szemléletet, hogy a kutatásokkal támogassuk az oktatáspolitikát. Akkor 
az egy nagyon új szemlélet volt. Szerintem ma már másra, vagy mondjuk úgy, többre lenne szükség, de akkor ez egy nagyon izgalmas, új dolog volt. Tehát újonnan indult az egész intézet, akkor verbuváltunk mindenkit, és olyan 10-20 emberrel indult a Kutatási Központ, zömében nők. Egy része Zsolnai Józsefnek dolgozott korábban, aki egy valódi iskolaalapító volt, saját módszereket is fejlesztett. Azt kell, hogy mondjam, hogy a kádári kor ellenére nagyonnagyon színvonalas volt az oktatáskutatás. Iszonyat sok innováció volt, kísérlet, tehát ilyen értelemben egy Kánaán volt. Nagyon jó, nívós kutatói gárda alakult ki ott a központban, és akkor azt is kell látni, hogy az Oktatási Minisztériumba a '90-es évek közepén bekerült oktatási államtitkárként Báthory Zoltán: egy olyan ember, aki kutató volt. Ilyen azóta sincs. És értette, hogy mi ez, tudta használni ezt az apparátust, és elindult egy stratégiai munka, egy evidence-based policy. Úgy éreztük, hogy van értelme annak, amit csinálunk: tényekre alapozott oktatáspolitikát, ahol mindent ezekkel a kutatási eredményekkel meg lehet alapozni. Érdemes talán még azt is megemlíteni, hogy az Education at a Glance mintájára - az OECD már elég erőteljesen elkezdett egy ilyen oktatásfókuszú munkát, ami 2000-től a PISA és egyebekben kiteljesedett - itthon is lett egy jelentés az oktatásról, és ez a „Jelentés a magyar közoktatásról” lett (Halász - Lannert 1995, 1997, 2000, 2003, 2006), és én kaptam meg ezt a feladatot. A fönökömmel együtt csináltuk, és kialakult egy olyan szinopszis meg egy munka, egy ritmus, ami ott aztán 10-15 éven át az egyik fó gerince volt a Kutatási Központ munkájának. Ez úgy nézett ki, hogy megvoltak azok a területek, hogy miket fedjünk le kutatásokkal. Mindig hároméves etapban dolgoztunk, és ez a három év úgy nézett ki, hogy az első félév egy tervezési szakasz volt, utána rengeteg háttéranyagot rendeltünk meg a különböző területekhez, és minden területnek - oktatásfinanszírozás, irányítás, eredményesség, továbbhaladás satöbbi - volt egy gazdája, az ún. fejezetgazda. Utána ezek a háttéranyagok bejöttek, és elkészültek a fejezetek. Ezeknek a fejezeteknek nagyon komoly szakmai vitája volt, bent is, kint is, minisztériumok meg egyéb szakemberek részvételével, és utána jött egy nagyon hosszadalmas műszaki szerkesztési folyamat. Azért mondom el ezeket, mert ma már ilyen nincsen; ma megírunk egy tanulmányt, és már arra sincs energia, hogy lektoráltassuk. Abban az időben ezek példaértékűen, rendszeresen mentek, és hihetetlen odafigyeléssel a tervezéstől a megvalósításon át a korrektúráig. Tehát kétszeres korrektúra volt, lektorálás és kétszeres korrektúra-forduló. Ma már gyakran egy könyvkiadóban sincs ilyen sajnos. Ez azért megadta a gerincét annak a munkának, ami ott 15-20 éven át zajlott.

K: Ki tudna-e emelni egy-két kutatási eredményt, ami ennek a keretében született? Ami Ön szerint fontos, és amelyek Önt motiválták a PhD témájában.

V: Ami szerintem egy izgalmas dolog volt, hogy csináltunk rendszeresen oktatásügyi közvéleménykutatásokat, három-négy évenként '90-től kezdve és még 2014-ben is volt egy, aminek megvan az adatbázisa, és nagyon gyakran hasonló kérdéseket tettünk fel: például, hogy mi a feladata az iskolának, mennyire elégedettek a színvonallal, satöbbi. Ez szerintem egy nagyon izgalmas adatbázis, még most is, és nemcsak oktatási célra, hanem arra is, hogy megértsük, hogy a rendszerváltástól hogyan jutottunk el idáig. Erről ezek az adatok elég sok mindent elárulnak. Szerintem ez egy nagyon izgalmas dolog volt, az már egy más dolog, hogy idővel elhalt, egyre kevésbé volt reflexív a politika, egyre kevésbé bírta a kritikát, egyre kevésbé lett szükség arra, hogy tényekre alapozódjon, így nem véletlen, hogy 2010-ben volt az utolsó „Jelentés a magyar közoktatásról", és ez elhalt. Én akkor már nem voltam az Intézetben, de még nélkülem egy megszületett, és a közvéleménykutatásokat pedig kifejezetten negligálták, mert jobban féltek attól, ami kijön, minthogy szembe nézzenek vele, és esetleg valamit kezdjenek vele. Itt azért egy nagy visszalépést látok. De ezek az adatbázisok megvannak, és nagyon izgalmasak. Ezek a jelentések ilyen értelemben azért voltak nagyon jók, mert empíria is társult ahhoz, amit megrendeltünk. És az egyik ez a közvéleménykutatás volt, a másik meg egy intézményi kutatás, tehát az iskolaigazgatókat kérdeztük meg különböző kérdésekről. Tehát ezek azért nagyon izgalmas adatbázisok, ráadásul ugye a néha ismétlődő kérdésekkel egy kvázi longitudinális elemzést is lehet csinálni rajtuk. Ezek biztos, hogy fontosak. Ezen belül én ugye a továbbhaladás fejezetet csináltam, és ez előbb-utóbb elvitt engem a témámhoz, a tanulási aspirációkhoz, amelyből a doktori dolgozatomat írtam, tehát annak ez biztos, hogy egy ilyen háttere volt. De más izgalmas dolgot is csináltunk, ami ma nagyon hiányzik, például oktatásfinanszírozással kapcsolatban felméréseket, akkor még az Oktatási Minisztériumban volt a Stark Antal, aki a Közgazdasági Egyetemen egy elismert figura volt. Akkor még volt az Oktatási Miniszté- 
riumban olyan ember, aki értett a statisztikához, a gazdasághoz, satöbbi. Ma ilyen nincsen. Ma nem is nagyon vannak a háttérintézetekben ilyen költséghaszon-elemzések, oktatás-gazdaságtani elemzések. Akiket még a Jelentés kapcsán kérdeztünk, azok a tanárok. Ilyen értelemben egy kincsesbánya volt az a munkahely, ahol én voltam, mert rengeteg empíriát csináltunk a jelentés miatt, és az empíriákat meg nagyon lehetett használni. Amiből a PhD-mat írtam, az meg speciálisan egy OTKA pályázat volt, amit négyen pályáztunk meg, egyikük Szabó Ildikó, aki sajnos már nem él. Elismert szociológus volt, főleg a fiatalok politikai szocializációjával foglalkozott, ő volt a kutatásvezető, és mellette voltunk még hárman. Három városban 13 és 17 év közötti fiatalokat kérdeztünk meg a továbbtanulási aspirációikról, aztán ez az empíria lett az én doktorimnak az alapja.

K: Milyen volt a témának a fogadtatása a doktori iskolában és a tágabb szakmai közegben?

V: Ebből a kutatásból ugye írtunk több tanulmányt, az Educatioban is jelent meg néhány (Lannert 1998, 2003a, 2003b), és hát elég jó volt a fogadtatása. Itt most hadd dicsérjem meg a doktori képzést, tehát a kutatási módszertant illetően nekem a doktori képzés adott pluszt, ellentétben a szociálpolitika képzéssel, ami érdekes volt, nem mondom, hogy haszontalan, de ott én egy kicsit olyan autodidakta módon tanultam a módszertant. És hiába tanultam a közgázon statisztikát, azért az nem olyan volt. Voltak olyan területei, amit egyáltalán nem tanítottak a közgazdaságin akkoriban. Most már vannak idősorelemzések, satöbbi, de akkor alapvetően lineáris algebrára építő optimalizációs feladatok voltak, és egy olyan alapstatisztika, ami lineáris regresszió volt, meg ilyesmi, és fóként folytonos változókkal. Ha az ember megkérdez embereket, akkor ez a folytonos változó maximum egy ötös osztályzat, hogy mennyire elégedett, de nagyon gyakran csak azt kérdezem, hogy egyetért-e vagy nem, és erre a nem feltétlenül mennyiségi változókkal történő elemzésre nagyon jó volt több oldalról is a doktori képzés. Tehát amit Füstös Lászlótól, Rudas Tamástól meg Moksony Ferenctől tanultam, többváltozós módszereket, mint a faktorelemzés, vagy az olyan izgalmas megközelítéseket, mint a kontextuális elemzés, ezeket nagyon jól tudtam használni a disszertációmban, mert szerintem eléggé újszerü is volt a megközelítés, meg az is, ami kijött nekem éppen ezzel a módszertani apparátussal.

\section{K: Kicsit még mesélne magáról a témáról?}

V: Igen, megjegyzem nem volt könnyủ ezt a témát megtalálni. Tudtam, hogy a továbbtanulással, továbbhaladással akarok valamit kezdeni, és azt hiszem az ELTE-n is volt valami hatalmas adatbázis, és gondoltam, hogy azzal csinálok valamit. Róbert Pétert kértem meg témavezetőnek. Emlékszem, hogy nem volt még világos a koncepció, csak annyi, hogy az valami továbbtanulással kapcsolatos lesz, és egyszer leültünk, és az a beszélgetés arra nagyon jó volt, hogy rájöttem, hogy még mindig nem tudom, hogy mit akarok csinálni. Tehát a Péter abban nagyon jó volt, hogy kérdezett, és kiderült, hogy valami nagyon nagyot akarok, de hogy pontosan mit is, az nem világos. Akkor rájöttem, hogy van ez a kisebb jellegű kutatás, ugye azért nem gondoltam erre, mert ez nem volt országosan reprezentatív, az ELTE-s kutatás meg igen. Ennek volt egy csomó egyéb vonzata, mert azt a módszertant, amit egyébként már a doktorimban használtam, a jelen pillanatig is ugyanezt a vegyes módszertant művelem. Ugye ahogy elindultam ebbe az irányba, hogy egyszerre interjúztam meg ugye az SPSS-sel is foglalkoztam, és a mai napig úgy gondolom, hogy a kettő együtt müködik. Ebben az OTKA kutatásban volt egy empíria, hogy a gyerekeket megkérdeztük, akik nagyon szívesen válaszoltak, szülőket is kérdeztük, ott se volt probléma, és mellette interjúztunk a három terepen az iskolákban, és megnéztük az oktatáspolitikai dokumentumokat. És akkor a Róbert Péterrel történt beszélgetés után rájöttem, hogy nagyon le kell csupaszítani a kutatási kérdést, és azóta is, ha bárki kérdezi kutató, én azt mondom, hogy nem szabad sokat markolni. Nem az a lényeg, hogy minél több adatbázisból valamit összekutyuljunk, hanem legyen egy kérdés. És nekem ennyi volt: hol és miért szeretnének továbbtanulni a fiatalok? Ennyi. Ennyi volt a kérdés, és végül is több mint 300 oldalon ezt a kérdést (nevet) jártam körbe, csak nagyon sokféle szemszögből. Ilyen értelemben ez a kutatási adatbázis nagyon jó volt, mert ebben is benne volt egy kvázi longitudinalitás, mert megkérdeztünk 13 és 17 éveseket. Nekem utólag ez volt az egyik fö eredményem kontextuálisan, hogy minél távolabb van a továbbtanulás konkrét ideje - a 13 évestől megkérdezzük, hogy akar-e egyetemen továbbtanulni, vagy dolgozni akar, meg a 17 évestől is -, annál inkább egy kulturális kód működik. Tehát annál inkább az történik, hogy akinek iskolázottak a szülei, az egyetemen akar tanulni, akinek nem, az nem, osztályzattól függetlenül. A 17 éveseknél már 
bejött egy racionális mérlegelés is, tehát nagyon jól lehetett látni, hogy az osztályzatok a korábbi elképzeléseket felülírhatták, és a kevésbé iskolázott szülők eredményes gyerekei is sokkal inkább akartak továbbtanulni, míg fordítva - mondjuk egy 3-as 4-es középosztálybeli tanuló is tovább akar tanulni, de mondjuk egy kettessel már nem. Ez azért ugye nem látszott 13 évesen. Ebből lehetett látni ezt a kontextuális hatást, hogy egyszerre hatott a kulturális kód meg a racionális mérlegelés a 17 éveseknél, a 13 éveseknél még ugye nem, ott elsősorban a családi adottságok és sztereotípiák működtek. Ezt nagyon szépen be lehetett mutatni. Illetve azt is, hogy a három különböző területnek a különböző iskolaszerkezete és oktatáspolitikája hat arra, hogy speciel hol akarnak továbbtanulni. Szombathely, Kecskemét és Békéscsaba három nagyon eltérő terület. A szülői adatokból lehetett látni, hogy Szombathely volt a legiskolázottabb, Kecskemét pedig a legheterogénebb, Békéscsaba meg egy kicsit olyan szocialista típusú hely volt. Az iskolaszerkezetet tekintve pedig azért volt érdekes, mert ezek a 6-8 évfolyam-típusú gimnáziumok akkor kezdtek el terjedni, de nem egyformán az országban. És nagyon érdekes, hogy Szombathelyen egyáltalán nem volt ilyen, nem volt szükség arra, hogy elkülönüljön a társadalom, mert nem volt olyan hierarchikus a társadalom. Kecskemét igen, és ott nagyon erőteljesen jelen volt a 6-8 évfolyamos gimnázium. Lehetett látni, hogy a helyi lokális iskolaszerkezet és a helyi társadalom nagyon erőteljesen együtt jár, az igényekre válaszol az iskola, és ez befolyásolja a gyerekek továbbtanulását. Tehát ugye van egyfajta kulturális kód, egyfajta racionális mérlegelés, és a harmadik a lehetőségek, és ennek a triangulumában dől el, hogy valaki továbbtanul-e vagy nem, és ha igen, hol. Ilyen értelemben Szombathelyen a szakképzés sokkal erőteljesebb volt, mert ott erősebb volt a helyi gazdaság. Békéscsabán érdekes módon a gimnázium mint továbbtanulás felülreprezentált volt, mert sokkal gyengébb volt a helyi gazdaság, ezért nem alakultak ki olyan erőteljes szakképző intézmények, ezért mindenki gimnáziumba ment, de ott se volt az a nagyon elkülönülő elit-magatartás, mint Kecskeméten, ahol a tanyavilág hihetetlen távolságra van a helyi elittől, ezt nagyon jól lehetett látni. Ilyen értelemben James Coleman után csináltam egy szegregációs mutatót, szerintem akkor az még nem nagyon volt Magyarországon, és miután az én adatbázisom megengedte, hogy ugyanazt a képletet használjam a különböző iskolázottságú szülőkkel rendelkező gyerekekre, mint amit ő kita- lált Amerikában a feketékre és nem feketékre, ezért az, ami a kvalitatív kutatásban, a dokumentumelemzésben látható volt az iskolaszerkezetre vonatkozóan, az nagyon szépen kijött az adatbázisból is. A legnagyobb szegregációs mutatót Kecskemét mutatta, talán Békéscsaba volt a legkevésbé szegregált, azért hívtam azt egy ilyen szocialistának, mert egy kicsit ilyen homogénebb és egyenlősítőbb volt a helyi társadalom és az iskolaszerkezet (Lannert 2005). Azt is tudni kell, hogy én féléven át dolgoztam úgy ezen, hogy a munkahelyemen is azt kértem, hogy akkor kapjak szünetet, és otthon is félévig a gyerekeim alig láttak, és azóta is ez családi viccelődések tárgya (nevet). Tehát a férjem és apósom nevelték fél évig a gyerekeket, és azóta is, hogyha csak meghallják, hogy $\mathrm{PhD}$, akkor összerázkódnak. Ezért a PhD-m egy hosszú köszönetnyilvánítással kezdődik az első oldalon, ahol megköszönöm a családomnak a segítségüket, mert enélkül nem ment volna. Tehát akkor féléven át csak ezzel foglalkoztam, mert nem tudtam volna különben megírni.

$K: A$ PhD-t követöen mi volt a következö lépcsö, hogyan változott meg a szakmai életútja, miben hozott ujat az, hogy megszerezte a PhD-fokozatot?

V: Talán annyi, hogy elvárás volt a vezetők felé a $\mathrm{PhD}$, én már kutatásiközpont-vezető voltam akkor vagy e környékén, de akkor ezzel megszilárdult ez a pozíció és bekerültem abba a bérkategóriába, ami ennek megfelelö. Tehát volt egy ilyen adminisztrációs kipipálás. Most utólag azt kell mondjam, hogy az én életem nagyon megváltozott aztán utána, és a $\mathrm{PhD}$ nekem formálisan jelen pillanatban nem jelent semmit. Annyit igen (mosolyog), hogyha interjúzni hívnak, és mondjuk, orvosok között vagyok - mert nagyon sokféle kutatást csinálunk már -, mert tudom, hogy vannak olyan rétegek, ahol ez fontos, hogy doktor, akkor odarakom a doktort a nevem elé, de csak azért, mert tudom, hogy anynyira hierarchikusan gondolkoznak, hogy ez nekik fontos, de szinte ennyi. Én azt gondolom, hogy a PhD-nak a formális tudományos életben van szerepe, én pedig pont nem formális tudományos életet élek éppen. Ilyen értelemben jelen pillanatban sem anyagi, sem pozícióbeli hatása nincsen az életemre. Én ezért azt szoktam mondani, hogy számomra a $\mathrm{PhD}$ valódi tanulás volt, és ott én tényleg nagyon sokat tanultam, amit azóta is hasznosítok a munkámban. Tehát nekem nagyon nem a papír része volt az érdekes, és bár átmenetileg akkor kellett az Országos Közoktatási Intézetben, de hosszútávon 
azt gondolom, hogy a formális karrieremre való hatása minimális.

K: Emlitette, hogy nem formális tudományos pályán dolgozik, ezt egy kicsit ki tudná fejteni, hogy mit ért ez alatt?

V: Hát ugye ezt már jeleztem, hogy nagyon izgalmas volt az OKI-ban a tényekre alapozott szakmapolitikai támogatás, ehhez célzott kutatások voltak, satöbbi, de - ahogy mondtam - egyre kevésbé lett reflektív a politika, és eljutottunk oda, hogy 2006 után, amikor a szocialisták vették át a szabad demokratáktól az oktatási tárcát, elindult egy olyan, a tényektől távolodó folyamat, ami máig tart. Szerintem akkor az történt, hogy tudták, hogy kellenek tények, de valójában csak arra kellettek, hogy amit eleve meg akartak csinálni, ahhoz kiválogassák és odategyék mellé. És nekem akkor már ez a fügefalevél szerep nagyon nem tetszett, és az történt, hogy olyan tendenciák indultak be még a Hiller alatt, hogy én fogtam és fölmondtam az Országos Közoktatási Intézetben, pedig vezető pozícióban voltam. Ez nem szokás, lemondani szokás, de én ki is léptem egy biztos közalkalmazotti státuszból, mert egyszerűen úgy éreztem, hogy az én kutatási szabadságom és a szakmai integritásom és amilyen irányban elindultak a folyamatok, azok nem kibékíthetők. És csináltam egy magán kutatócéget, de nem egyedül, és ez nagy segítség volt. Korábban már említettem, hogy nekem a TÁRKIval már régóta, már a közvéleménykutató cég óta volt kapcsolatom, de a TÁRKI-val együtt dolgoztunk többször a Jelentés kapcsán is, és Tóth István Györggyel én jóban is voltam, és akkor neki volt az ötlete, hogy csináljunk egy céget. Akkoriban a TÁRKI több ilyen leánycéget is csinált, és együtt hoztuk létre akkoriban a TÁRKI-TUDOK Tudásmenedzsment és Oktatáskutató céget, és ez azért is volt nagyon jó, mert ugye ilyenkor pályázatból él az ember, és a pályázatoknál viszont, ha közbeszerzés, akkor bizonyos bevételt el kell érni, viszont így a TÁRKI hátterében mi már nagyon hamar be tudtunk lépni erre a piacra. Kaptunk anyagi segítséget is, nagyon sok segítséget kaptunk a TÁRKI-tól, hogy felépítsük ezt a céget. Nem mondom, félévig úgy ültünk öten a szobában, hogy elöször nem voltak munkák, és akkor, hogy mégiscsak dolgozzunk, mi magunk találtunk ki munkát magunknak. Az első ilyen munkánk a „Kié lesz az általános iskola?” volt. 2007-2008 környékén már lehetett látni, hogy finanszírozhatatlan a magyar közoktatás, és ezért megjelentek magánszereplők, meg kistérségi társulások, tehát különböző módon próbálta az akkori rendszer megoldani, hogy ezek az iskolák mégis legyenek. Érdekes volt, hogy hol mi történik, és három helyre mentünk el. Az egyik Kiskőrös volt, ahol egy hatalmas konglomerátumot csináltak, egy olyan kistérségi társulást, ahol 30-40 intézmény volt együtt. Elmentünk Zalába, ahol meg pontosan egy kistérségi társulás volt, de a falvak nem akartak bemenni a városok alá, ezért 7-8 kis falu összefogott, meg a szülők, és próbálták így fönntartani az iskolát. A harmadik pedig Győr környékén volt, ahol egy oktatási vállalkozó nagyon furcsa körülmények között egyszerűen megvett bizonyos iskolákat. És akkor ezekre a településekre lementünk, interjúztunk, és hát azt szoktam mondani már akkor is, hogy a kutatás az majdnem olyan, mint egy detektívtörténet, egy krimi. Ott szó szerint az volt, mert Győr környékén effektíve követtek minket, mert az valami sundám-bundám lehetett, és azt gondolták, hogy valamilyen tényfeltáró riporterek jöttek, hogy utána járjanak (mosolyog), és hát igen, nagyon érdekes történetek voltak ezek. És hát ez volt az, amit tulajdonképpen összeraktunk, és csináltunk sajtótájékoztatót, és elég jól szólt. Azt hiszem éppen jókor, jó helyen, jó kérdést tettünk föl, és ez volt a debütálásunk. Utána viszont kaptunk egy nagyon szép feladatot, amivel igazából el tudtunk indulni, a koraintervenciós rendszer átvilágítását és itt ugye rögtön azzal szembesültünk, hogy ugye hiába közoktatás a föprofilunk, de ennél nekünk szélesebb spektrumon kell mozognunk. Ez a kutatás tulajdonképpen arról szólt, hogy a 0-3 éves gyerekekkel és sérült gyerekekkel mi történik, hogy működik a rendszer. Ez egy nagyon nagy kutatás volt, ahol orvosok, védőnők, gyógypedagógusok vettek részt, tehát egy nagyon széles területen raktunk össze valamit és az is nagyon jól sikerült szerintem. Lassan így elindult a szekér.

K: Arról már volt szó, hogy korábban is volt vezetö, illetve ebben cégben is. Ez az ön életében milyen szerepet töltött be, hogy nemcsak kutató, de vezetö is volt?

V: (nevet) A Közoktatási Intézetben az az érdekes, hogy én úgy lettem vezető, ahogy a nők általában vezetők lesznek, hogy hirtelen lesz egy üres tér, és hirtelen nincs, aki betöltse, és akkor viszont jól jönnek a nők. Tehát nem volt ott senki férfi, aki nagyon akarta volna, mert ugye a Halász Gábor volt, de akkor ő az intézet vezetője lett, és megüresedett 
a pozíció, és megkapta utána két idősebb kolleganő, akik egy idő után viszont elfáradtak. Máig emlékszem, ez úgy nézett ki, hogy ültünk a Kutatási Központ értekezleten és azon merengtünk, hogy ki legyen a vezető. Mert nehogy már kívülről jöjjön valaki, de belülről senki nem akarta vállalni, mert hát ugye ki akar vezető lenni, ha kutathat, és emlékszem mindenki meredten nézett maga elé, és én egy kicsit előbb fölnéztem, és akkor mindenki rám nézett. Szóval ez így történt, hogy rám néztek, és eldöntötték, hogy én leszek. Ez egy olyan történet volt, hogy én nem azért lettem vezető, mert ezt én ambicionáltam, hanem valahogy megtalált ez a feladat. Amikor megtalált, akkor viszont szerintem én elég tisztességesen beleálltam, próbáltam komolyan csinálni. Nem vettem részt semmilyen vezetőképzésen, de elkezdtem olvasni menedzser könyveket. Azt hiszem a közgáz háttér sokat segített, nem a bölcsészkarról jöttem, mint a kollégák többsége, és ilyen értelemben azt hiszem, előnyben voltam. Mindenkivel leültem egyesével megbeszélni, hogy ö nekik mik a vágyaik, a központnak mi kell, és megpróbáltam ezeket összefésülni. A központi feladatokat ezek alapján lebontottam egyéni feladatokra, és elvártam, hogy dolgozzanak, de már az elején megmondtam, hogy engem nem érdekel, hogy ki mennyit dolgozik, hanem az eredmény a fontos, és ha valaki sokat dolgozik, de nincs eredménye, ne jöjjön nekem sírni, mert akkor előbb-utóbb megválunk tőle. Tehát azt gondolom, hogy volt bennem keménység is, nem féltem a konfliktusoktól, és volt ilyen is, leépítéseket kellett csinálni, és azt kell, hogy mondjam, hogy három kollegát úgy építettünk le, hogy megnéztem, hogy ki az, aki utána tud továbbmenni, és mindenkivel jó viszonyban maradtam, tehát ez olyan barátságosan történt. És amikor azt kérték, hogy még egy negyedik embert is le kéne építeni, akkor azt mondtam, hogy itt vagyok én, és akkor azt mondták, hogy jó, akkor nem. Én azt gondolom, hogy föl kell vállalni a konfliktusokat is, de ésszel, tehát a feladatot úgy kaptam meg, hogy nem voltak vezető ambícióim, annak idején, amikor a közvéleménykutatóban azt a pszichológiai tesztet nézték, akkor azért is tetszettem meg nagyon mindenkinek, mert a magas IQ mellett nem volt bennem a vezetői ambíció, tehát egy ilyen horizontálisan együttműködő típus voltam. Igazából izgalmas volt, nagyon sokat tanultam, és azt gondolom, hogy mindenkinek jó lenne, ha vezető is lenne egy ideig, mert egész más onnan a perspektíva. Mert most is szeretünk szidni politikusokat, akárkiket, de aki volt olyan pozícióban, az tudja, hogy onnan egész más, és sok minden tényezőt kell együtt figyelni. Én, ha tehetném, mindenkit félévig vezetővé tennék, mert akkor egy kicsit kiegyensúlyozódna a dolog, nem sírnának annyit, és megértenék, hogy a másik oldalon is vannak azért különböző feladatok meg korlátok. Azért volt nekem még egy ilyen kurfli, tehát amikor megcsináltam ezt a kutatóintézetet és elindult, aztán viszont beragadt 2010-ben, és hát ez azért a Fidesszel összefüggött. Tehát sajnos nem tudja megúszni az ember, hogy közoktatás-kutatás és pályázat, sajnos ez valamenynyire a policyval és így a politikával is összefügg, és föleg ezek az uniós pénzek bejönnek-kimennek, tehát egy ilyen stop and go rendszerben nagyon hektikus volt a bevételünk, ami nagyon nagy kihívás. Míg közalkalmazottként az volt nagy kihívás, hogy ugyan biztos volt a bér, a háttér, de nem volt szabad az ember, itt most szabad volt, azt csináltunk, amit akartunk, de a bevételek ezért iszonyat hektikusak voltak. Volt, hogy ott is meg kellett válni kollegától, és ez mai napig egy probléma, hogy hogyan tudok fölnevelni kutatót magunk mellett úgy, hogy közben nem tudom feltétlen biztosítani a bérezést biztonságosan. Ezért 2010-ben az történt, vagy talán 2012-ben volt ez, hogy megtalált újra az Országos Közoktatási Intézet jogutódja, az Oktatáskutató és Fejlesztő Intézet. Akkor már Hoffmann Rózsa volt az igazgató, és megkértek, hogy nem lennék-e ott programvezető. Amit én ott azzal a feltétellel fogadtam el, hogyha én ott tudományos fóigazgató-helyettes leszek. Ez az a poszt, ami mindig ott volt az SZMSZ-ben és soha nem töltötték be. Fél évig volt betöltve, amikor én ezt elvállaltam. Hát ez különböző problémákat okozott, a TÁRKI ezen berágott, és azt mondta, hogy nekik innentől kezdve ez a cég nem érdekes, ha én nem vagyok benne, pedig a kolléganőm vitte volna tovább, és akkor innentől T-TUDOK néven átkerült egy másik cégcsoportba, és egy kolléganőm, Németh Szilvia vitte tovább. Én pedig visszakerültem egy másik kolléganőmmel, Sinka Edittel az Intézetbe. Ez félévig tudott menni, mert orbitális dolgok történtek velem, például átírták a velem készült interjúkat. Ami ott zajlott, az az, amit most már mindenütt lehet látni, de ez volt már 2012-ben is, és bekövetkezett, hogy én másodszor is felmondtam, egy nagyon izmos és nagyon jól megfizetett állásból. És utána, én ugye korábban vezérigazgatója voltam a TÁRKI-TUDOK-nak, az is egy izgalmas feladat volt, de én papíron már nem mentem vissza ehhez a céghez, úgy vagyok ott, hogy nem vagyok ott, és erre szoktam mondani, hogy én most elértem azt, hogy egy névjegykártyára 
csak azt írnám rá, hogy Lannert Judit, az is müködik. Ez egyfajta „szakmai csúcs”, hogy már nem kell semmilyen intézmény mögötted, mert már a nevedet ismerik, és tudják, hogy ki vagy. Tehát én most per pillanat ebben a szituációban vagyok. A kolléganőm viszi, Németh Szilvia, és én dolgozom a cégben, és nagyon sok izgalmas dolgot csinálunk, de én most már ilyen értelemben azt mondhatom, hogy az elitek elitjébe tartozom, mert Magyarországon szabadon gondolkozhatom, és szabadon élhetek.

\section{K: Egy kicsit mesélne azokról a kutatásokról, ame-} lyekkel mostanában foglalkozik?

V: Akkor annyit mondanék, hogy jeleztem ugye, hogy mennyire izgalmas volt, hogy oktatáspolitikával foglalkoztunk az OKI-ban, és ez nagyon fontos is volt, viszont van egy olyan dolog, amit én, amikor tudományos főigazgatóként odakerültem, nagyon szerettem volna megoldani, egy régi probléma, de nem sikerült, hogy az oktatásfejlesztés az kutatásra épüljön. Azt úgy kell elképzelni, hogy voltak a fejlesztők, meg voltak a kutatók. És a kutató az leginkább azt kutatta, hogy hány roma gyerek hol van, és satöbbi, de nem kutatta magát a tanítás folyamatát, mert szociológusok voltak ott. Mert ugye az oktatáspolitika, meg ez volt a fontos. Viszont a fejlesztők, azok meg nem nagyon tudnak mérni, mert nem értenek hozzá, ő nekik van egy tacit tudásuk, tehát próbaszerűen kísérleteznek, bejön, nem jön be, fejlesztenek. Azt gondolom, hogy a mai világ az oktatáskutatásban, ahogy a PISA-ban is, arról szól, hogy meg lehet-e mérni a kompetenciákat. Mindenféle tanítási-tanulási folyamatnak a fejlesztésre kell irányulnia, és ha arra irányul, akkor viszont azt úgy kell csinálnunk, hogy tudnunk kell, hogy mit akarunk fejleszteni, azt mérni kell tudnunk, megfigyelni, kontrollcsoporttal satöbbi, megnézni, hogy mi zajlik valójában, és a fejlesztést ilyen irányba vinni. Ez nem sikerült az OFI-ban, viszont sikerült a cégben. Most ott tartunk, hogy nemcsak kutatunk, hanem fejlesztünk is, és van egy nagyon sikeres programunk, a Kreatív Partnerség Program, aminek az a lényege - egy angol fejlesztést adaptáltunk -, hogy a művészeket bevisszük az osztályterembe, akiket kiképzünk erre, és nem az a feladatuk, hogy művészetoktatást csináljanak, hanem az, hogyha az iskolának bármilyen pedagógiai vagy tantárgyi problémája van - például nem megy a gyerekeknek a történelem, vagy a matematika -, akkor ezek a művészek a tanárral együtt kreatív megoldásokat találjanak ki az adott tantárgyban a tantervi kereteken belül. Mi a matematika területen elindítottuk ezt önerőből, saját pénzt is raktunk bele, és ilyen értelemben jó a vállalkozás, mert nem kell várni arra, hogy valaki téged majd megfizet igen, a zsebedbe kell nyúlni, de mégis ad egyfajta szabadságot. Mi ebben nagy fantáziát látunk, és Pécsett öt iskolában el is indult ez a program, 3-4 éve föleg matematika területen, de töri meg ilyenek is voltak. Mértük is kontrollcsoporttal, hasonló hátrányos helyzetű gyerekekkel, akik nem vettek részt a programban - a matematikát mértük, és szignifikánsan javult a leghátrányosabb, SNI, cigány gyerekek matek tudása ezzel, hogy beléptek ezek a művészek az osztályterembe. Fontos leszögezni, hogy a művészek nem a tanár helyett dolgoznak, hanem a tanárral együtt. Tehát igazából az a zseniális ebben az egészben, hogy a tanár szemléletét megváltoztatja anélkül, hogy a tanár frusztrálva érezné magát, vagy úgy gondolná, hogy nem csinálja jól. Általában nem csinálja jól, de miután bejön ez a két fiatal, megnézik együtt a tantervet, óraterveket és közösen ötletelnek, hogy mi működne és mi nem, és ebbe a tanárt bevonják, elindul a tanár agya is, ami sajnos nem jellemző a normál közoktatásban, a kreativitás egyáltalán nem jellemző dolog, de itt elindul. Olyan történeteink vannak, hogy például egy diszkalkuliás kislánynak olyan módszerrel segítettek, hogy a művészek kitalálták, hogy akkor most menjenek ki a térbe, és akkor az egyenleteket ilyen zsinórokon nézzék, és attól, hogy 3D-ben és mozgással volt illusztrálva, ez elindított egy másfajta gondolkodást. Ez a kislány azóta megtáltosodott, ötösöket ír matematikából. E mögött, amit mi csinálunk, van egy komoly tudományos háttér, a kreativitásnak öt területe, és hogy a kompetenciákat hogyan lehet fejleszteni. Az, hogy mi ezt csináltuk, ez az OECD-hez is eljutott, és miután a PISA-ban a kreativitást is akarják majd mérni, ezért most van egy kutatási programjuk, és ebbe minket meghívtak, egy ilyen pilotba két évre, most van vége, mert, hogy nagyon kevés program van, ami kreativitásra irányul és mért eredménye van. Az egy magyar adalék, hogy ebbe mi úgy léptünk be, hogy Magyarországot képviseltük, de az ország pénzt nem adott hozzá, azt mondták, hogy persze vegyünk részt, engedélyezik, meg azt is, hogy a pénzt összekalapozzuk hozzá. Amikor félidőben kiderült, hogy ez egy sikeres program és az OECD-ben Magyarországot kiemelték, akkor esett le itt egy-két embernek, de még nem mindenkinek, hogy ez a program menynyire jó lenne. Ritka, hogy az OECD-ben magyar fél irányító pozícióban tud részt venni egy kutatás- 
ban, és nem csak követünk valaki nagyokosokat. Tehát ebben a programunkban meg tudtam végre valósítani azt, amit az OFI-ban tudományos fóigazgató-helyettesként nem nagyon sikerült, hogy az az innovációs kör összeérjen, ahol kutatásra épül a fejlesztés és folyamatos visszacsatolásban fejlődik az egész folyamat. Tehát ilyen értelemben eltávolodtam, nagyon távol áll tôlem az akadémiai élet. Vezetek egy blogot is, pontosan azért, hogy közérthetö nyelven tudjak valamit írni. És azt kell, hogy mondjam, szakdolgozatokat, doktorikat megkapok, tehát ilyen értelemben bár én nem vagyok a formális tudományos szcénának a szereplője, de megtalálnak, és nagyon kritikus vagyok, és azt találom, azt látom, hogy az akadémiai élet elvesztette a fókuszát: formalizált, a helyesírási szabályok, és a szakirodalom helyes hivatkozása az szinte fontosabb, mint hogy valami értelme is legyen annak, amit leírnak. És nem látom azt benne, mint amit az én munkámban, ahol én úgy érzem magam, mint Miss Marple, hogy van egy adatbázis, egy probléma, és akkor keressük a tettest, és a végén kiderítjük. És valóban mindig valami hoppá van a végén. Az akadémiai életben azt látom, hogy jönnek fiatalok is, de azt látom, hogy nem érdekli őket a probléma. A kíváncsiság, ez a legfontosabb, én most is baromi kíváncsi vagyok, hogy mi lesz, és ma is épp azt néztem, hogy mit gondoltak 2014-ben a tanulásról a felnőttek - nem az a fontos, hogy hány előadást tartottam, hogy az irodalomjegyzékében hány publikáció van, hogy mindenhova odaírjam a nevemet, hogy valami pozícióhoz jussak, hogy majd a doktori cím ott legyen a nevem előtt. Ez mélységes utálattal tölt el (nevet). Ha írok egy tanulmányt, előfordul, hogy visszakapom azzal, hogy bulvár szaga van, mert mondjuk a címe az, hogy „Sokkhatás a digitális szövegértés terén", de hát ilyet nem lehet - legyen minél unalmasabb, mert annál tudományosabb. Legyen az, hogy a digitális szövegértés helyzete Magyarországon 2000-nem-tudom-hányban. Miért ne írjam bele a lényeget, ami miatt megírtam? Mi hál'istennek nagyon széles spektrumon mozgunk. Nemrég egy felsőoktatás-kutatásban vettünk részt, jelenleg pedig van egy „Biztos Kezdet” étékelésünk, ahol egyéves gyerekeket kell megfigyelnünk, és mérni majd a fejlődésüket. Tehát, hogy van egyfajta széles spektruma annak, amit csinálunk: a felnőttek tanulásától kezdve az egyetemistákon át az egyéves gyerekig. És ez nagyon más eszközöket igényel, ezért azt szeretem, hogy mi is kísérletezünk. Tehát újfajta módszereket használunk. Volt most egy drogos kutatásunk a szegregációban általános iskolás gye- rekek droghasználatáról, és akkor kitaláltunk olyan fókuszcsoportos technikákat, amiket még nem használtak, de azt gondoltuk, hogy ez jó lesz. Egy sztori-kocka módszert, egy drámapedagógiai módszert, meg egy ilyen Kreatív Partnerség művészeti módszert. Egyfolytában kísérletezünk, úgy, hogy ezt mindig mérjük is, tehát ha már a kreativitással foglalkozunk, akkor már bennünk is legyen. Ez a kreativitás a mai magyar tudományos életben... hát nem tudom... tehát mi ugye gyakornokokkal is dolgozunk, szeretem, mert fiatalok és szeretnének tanulni és dolgozni, de olyan alapvető dolgok hiányoznak, mint az íráskészség, a fókuszáltság, és leginkább a kíváncsiság, hogy ez most miért van, és hogy én mindenáron meg akarom tudni, és jól megtudni, mert a módszerek persze fontosak. Ehelyett a publikáció számukra inkább a kötelező kűr: „van egy publikációm, és akkor végre ott van az irodalomjegyzékemben plusz egy sor”.

\section{K: Ön szerint hogyan lehetne ezen változtatni?}

V: Hát ugye vissza kellene térni a közoktatáshoz, mert a PISA eredmények alapján is látszik, hogy a magyar közoktatás színvonala nem kiemelkedő. Hál'istennek vannak elérhető adatok, és így legalább ezt tudjuk, és ezt szerintem fontos tudni, még ha nem is jó látni. De ez még mindig jobb, mintha nem tudnánk. Most ugyanez a színvonalesés figyelhető meg, a felsőoktatásban halmozottan. Én ezt két oldalról is látom, a gyerekeim elérték az egyetemi kort, egyikük már túl is van rajta, a másik még benne, de abbahagyta, és láttam, hogy a tanulás már egész másról szól ma, és ugyanazokat a problémákat látom a felsőoktatásban, mint a közoktatásban. Nem élményszerủ az oktatás, egyszerủen a gyerekek nem értik, hogy miért jó tanulni, mert nem izgalmas. A Kreatív Partnerség keretében, ott játszanak, mozognak, és úgy tanulnak meg dolgokat, hogy nem is veszik észre. Nagyon aranyos, meg szokták kérdezni, hogy oké, de mikor kezdünk el tanulni? Nem vették észre, hogy végig tanultak, csak hát nem úgy, ahogy egyébként szoktak, hogy ülünk, és dögunalom az egész, mert a tanár folyamatosan kinyilatkoztat. És azt hiszem az egyik probléma a tanár szerep, és ez a felsőoktatásban is érvényes, hogy nálunk egy hierarchikus rendszer van, az interjúk alapján is ezt látom. Egy ismerōsöm elmondása alapján egy rektori konferencia úgy kezdődik, hogy egy órán át mindenki felsorolja a többiek címét, meg a sajátját. Tehát tulajdonképpen nem tudnak eljutni a valódi problémáig, mert 
túl sok idő megy el azzal, hogy körbeudvarolják egymást és fényezik magukat. Fontos, hogy megadjuk a tiszteletet, de erre nagyon sok idő megy el. És ugyanez a merevség, tekintélyelvűség a baj a tanári szereppel; nem szabad hibázni, a tanár se hibázhat, a gyerek se hibázhat - ez megöl minden kreativitást és kísérletezést. És ugyanez van a felsőoktatásban is, pedig igenis, lehessen hibázni, csak éppen utána a hibát ki kell javítani, tehát nem azt mondom, hogy rossz tanár legyen, de nem attól rossz tanár, hogy hibázik, hanem hogy észre se veszi, hogy nem jó, és nem javít ezen. A jövő oktatása és tanulása egészen máshogy fog menni a digitális technikák miatt, tehát ilyen értelemben sokkal inkább egy partneri viszonynak kellene kialakulnia az oktató és az oktatott között. Olyan gyorsan változnak a dolgok, hogy lehet, hogy az oktatott is tud valamit átadni az oktatónak. Emlékszem, Skóciában mondták az egyik iskolában, hogy nem értenek az informatikához, de a 10 éves gyerekek igen, és megkérték a tanárok az egyiket, hogy tanítsa őket. A 10 éves gyerek fogta magát, és kurzust tartott a tanároknak. Hát erről van szó, hogy sokféle tudás van, de ez a fajta hierarchikusság, tekintélyelvűség, ami belengi az egészet, ettől az egész teoretikus, elméleti, nem igazán gyakorlatorientált lesz. Ami persze nem jelenti azt, hogy ki kellene dobni az elméletiséget, ez egy pozitív dolog ma is a magyar oktatásban, és nem kellene kidobni az ablakon, mert igenis komoly elméletek is vannak, de akkor lesz AHA élménye a tanulónak, ha az új tudást tudja kötni valamihez. Mint ahogy a statisztikában, ha a feladat az optimalizációs gyakorlatnál nem az lett volna, hogy a lépegető eszkavátorokból ennyi jön be az országba, és ennyi van raktáron, és akkor ebből hogyan tudjuk a logisztikát optimálisan megoldani, hanem mondjuk a feladat egy optimális iskolahálózat kialakítása, ahol el kell érni, hogy minden iskolában 10-20\%-nál ne legyen magasabb a romák aránya, de ne kelljen öt kilométernél többet utazni egy gyereknek, ez is egy optimalizációs feladat. Én, ha ilyet kaptam volna, akkor lehet, hogy nagyon hamar sokkal izgalmasabb lett volna számomra a statisztika. Én ilyen értelemben azt gondolom, hogy sokkal inkább érdekesnek kellene lennie, kíváncsinak lenni magának a tanárnak is, és nem ez a fajta formalizált rendszer kellene. Például amikor kérdőívet csináltunk egy állami megrendelőnek, egy hónapon át csak azon rugóztak, hogy milyen helyesírási hibák vannak benne, egy vesszőhiba, satöbbi. De senki nem nézte, hogy azok a kérdések jól vannak-e feltéve vagy jól lehet-e elemezni, halálba kergettek vele, de tényleg. Azt gondolják, hogy tényleg ez a legfontosabb, pedig szerintem nem.

$K:$ Es esetleg tudna valamilyen tanácsot adni azoknak, akik most PhD-képzésre jelentkeznek, akik kutatók szeretnének lenni? Hogyan álljanak neki a kutatói életpályának?

V: Hát, amit mondtam, hogy ki kell menni a terepre. Az MA után ne menjen senki rögtön $\mathrm{PhD}$ ra. Ki kell menni az iskolából, csinálhat akár egész mást, az élet azért annyi minden másról szól. A gyerekeimen látom ezt föleg: a legidősebb az még tantárgyakat tanult, a középső az már ezt nagyon negligálta, de a harmadiknak már semmi köze nincs a tantárgyakhoz, és mégis fejlödik, mert egy csomó minden mást csinál, mert tényleg igaz, hogy a kompetenciák már nagyon sokféleképpen fejlődnek. Tehát amit csinálnak nyugaton, hogy egyetem után egy évre elmennek önkéntesnek, és körbeutazzák a világot, tehát ilyeneket kellene csinálni. Nem szabad az iskolapadból az iskolapadba bemenni, mert akkor nem lesz érzékeny arra, hogy bullshiteket tanul. Ha ezen túlmegy, akkor rögtön fogja érezni, hogy ennek most van értelme, vagy nincs értelme, és hogy egyáltalán mit akar. A másik, hogy csak akkor menjen PhD-ra, ha tényleg kíváncsi, azért ne menjen senki, mert azt gondolja, hogy ezzel majd többet keres, vagy hogy olyan szépen néz ki a professzori cím, meg majd utazni lehet vele. Tehát ha nem érdekli az a probléma és nem ezzel kel föl reggel és fekszik le este, akkor ne menjen PhD-zni. Ha nekem van egy kutatásom, akkor nekem egy idő után tényleg már csak az megy a fejemben. Ez eléggé borzasztó is, de utána meg annyira jó, amikor a végén meg megvan a tettes. És akkor tudom, hogy oké, a nyomozásnak vége, és sikeres volt. Ha nincs ilyen, akkor csináljon mást, mert annyi szép dolog van a világban. És a harmadik, hogyha valaki nem tud írni, akkor ne jöjjön, az egy alap, és azt gondolom, hogy ebben nagyon ludas a közoktatás, régen azért sokkal több esszét kellett írni, bármiről, és most nem. Tehát vannak ezek a „multiple choice” tesztek, satöbbi, és egyszerüen elsikkadt az írás, pedig az nagyon fontos. Lehet fejleszteni, de akkor arra rá kell dolgozni.

\section{K: És ha visszatekint a pályafutására van-e esetleg valami, amit máshogy csinált volna? \\ V: Ez olyan hipotetikus, nem igazán tudom... Talán egy dolog, hogy én beszélek angolul, nem is rosszul, meg valamit németül és franciául is, de}


azért nem tudok igazán jól írni angolul. Tehát ha lehetne visszamenni, lehet, hogy sokkal inkább ezen a téren is kellett volna fejleszteni magam. Igaz, hogy Princetonban voltunk egy évig, és azért az nagyon sokat is használt, de túl azon, hogy jól beszélek, nincs problémám, meg is írom, tehát nem erről van szó, de a felsőoktatás nemzetköziesedéséről szóló kutatásunk során azt találtam, hogy megdöbbentöen kis arányban használnak külföldi szakirodalmat a BA képzésen, MA-n is alig. És szinte mindenki azt mondta, hogy a nyelvtudás hiánya az akadály, nem a pénz. Tehát azt gondolom, hogy ehhez képest én jól állok, de még az én szintemen is érzem, most például a CEU-n adtam elö, és most kellene írni egy angol tanulmányt, meg is fogom írni, de érzem, hogy a legnagyobb lányom Londonban dolgozik már három éve, és ő nagyon jól tud angolul, hogy azért az egy más szint. Tehát ha lehet ez, akkor az lenne jó, ha angolul is olyan jól tudnék írni, mint magyarul (mosolyog).

K: Zárókérdésként azt kérdezném, hogy mi az, amit még mindenképpen el szeretne érni kutatóként, mik a jövöbeli tervei?

V: Ezt inkább fordítva mondanám: mi az, amiről már lemondtam (nevet). Mert ugye a közoktatás az egy public policy, ha az ember ezen dolgozik, akkor azért szeretné látni, hogy hat. Én most már erről lemondtam, hogy bárminemủ ráhatásom legyen arra, ami itt az oktatáspolitikában zajlik. Ez egy nehéz dolog ezzel együtt élni, mert nem így lettem szocializálva, de ha így élnék tovább, akkor ezt a feszültséget nem tudnám elviselni. Ilyen értelemben azt gondolom, hogy nem könnyủ kutatói székben közpolitikát csinálni, amit az államnak kellene, de nem csinálja. Amit igazán szeretnék, hogy ne ilyen hektikus legyen a cég bevétele, hanem az a sok jó, amit csinálunk, az egy biztonságosabb finanszírozással tudjon menni, ez lenne jó - ez még nem egy egyéni kutatói, hanem inkább egy vállalkozói kívánság. Kutatóként azt tudnám mondani, hogy vannak témák, amikből könyveket írnék, és ezeknek a könyveknek a megírása, ami legalább három téma, ha nem több, de ezt nehéz, ha az embernek a létezése projektektől függ, és igen, könyvet írni könnyebb lenne, ha bemennék az egyetemre vagy az akadémiára, de nincs az a pénz, hogy én oda bemenjek. Tehát most ez van, hogy a projekteket meg csinálni kell, és amellett meg nem nagyon lehet sabattical-ra elmenni, de ha el lehetne menni, akkor egy ilyen könyvírás, az jó lenne.
K: Sok sikert kivánunk ehhez és köszönjük szépen az interjút.

\section{Felhasznált irodalom}

Halász G. - Lannert J. szerk. 1998 Jelentés a magyar közoktatásról 1997. Budapest, Országos Közoktatási Intézet.

Halász G. - Lannert J. szerk. 2000 Jelentés a magyar közoktatásról 2000. Budapest, Országos Közoktatási Intézet.

Halász G. - Lannert J. szerk. 2003 Jelentés a magyar közoktatásról 2003. Budapest, Országos Közoktatási Intézet.

Halász G. - Lannert J. szerk. 2006 Jelentés a magyar közoktatásról 2006. Budapest, Országos Közoktatási Intézet.

Lannert J. 1988 Reformok a japán oktatásban. Oktatásügyi kutatások 5. Budapest, Oktatáskutató Intézet, 117-132.

Lannert J. 1993 Az ifúsági munkanélküliség kezelése Nyugat-Európában a nyolcvanas években. In Halász G. szerk. Az oktatás jövoóje és az európai kihivás. Budapest. Educatio Oktatáskutató Intézet, 181-202.

Lannert J. 1998 Pályaorientációk. Educatio, ősz, 436-446.

Lannert J. szerk. 2003a Hogyan tovább? Pályaválasztási aspirációk a tizenévesek körében három kistérségben. Budapest, Országos Közoktatási Intézet.

Lannert J. 2003b Középiskola-választás a kilencvenes évek végén. In Nagy M. szerk. Mindenki középiskolája. Középfokú képzés az ezredforduló Magyarországán. Budapest, Országos Közoktatási Intézet, 71-92.

Lannert, J. 2005 Pályaválasztási aspirációk. (A 13 és 17 évesek továbbtanulási aspirációi mögött munkáló tényezők három kistérségben). Doktori (PhD) értekezés, Budapesti Corvinus Egyetem, Szociológia Doktori Iskola. 